\title{
PELAKSANAAN PROGRAM KEBIJAKAN DESA MANDIRI DALAM MENINGKATKAN KESEJAHTERAAN MASYARAKAT DI DESA NAGROG KECAMATAN CICALENGKA KABUPATEN BANDUNG PROVINSI JAWA BARAT
}

\author{
Oleh
}

\author{
Rusmini \\ Institut Pemerintahan Dalam Negeri \\ rusmini.waluyo@gmail.com
}

\begin{abstract}
$T$ is study examines the problems that arise in the course of the village of civilization. Limited human resources, facilities, and lack of pre-program training in Nagrog Village. The purpose of this program is to help the Government and the community overcome the problems: capital or funds, development and productive labor intensive activities in realizing an independent village. The method used by the writer is a qualitative method with a descriptive approach. The process of collecting data by observation, interview and documentation.

The results of this study indicate that the implementation of the program in the village of Nagrog village of civilization is divided into two parts, namely the implementation process and the purpose of implementing the village civilization program. In the process of managing the organization it is divided into two programs, namely the civilization village OKMS and BUMDes. The stages of the process are explained: the preparation phase of the activity, the implementation phase, the management of the organization, the mechanism for sending aid, for evaluation and reporting. The purpose of the civilization program in the village of Nagrog illustrates how business management through BUMDes and how to implement infrastructure projects managed by OKMS.
\end{abstract}

Keywords: implementation, policies, programs, villages, and civilization

\section{AbSTrak}

Penelitian ini mengkaji masalah yang muncul dalam perjalanan desa Mandiri. Keterbatasan SDM, fasilitas, dan kurangnya pelatihan pra program di Desa Nagrog. Tujuan pelaksanaan program ini, untuk membantu Pemerintah dan Masyarakat mengatasi masalah: permodalan atau dana, pembangunan dan kegiatan padat karya produktif dalam mewujudkan desa mandiri. Metode yang digunakan penulis, yaitu metode kualitatif dengan pendekatan deskriptif. Proses pengumpulan data dengan cara observasi, wawancara dan dokumentasi.

Hasil penelitian ini menunjukkan bahwa pelaksanaan program di desa Mandiri Desa Nagrog dibagi menjadi dua bagian, yaitu proses pelaksanaan dan tujuan pelaksanaan program desa Mandiri. Dalam proses pengelolaan organisasi dibagi menjadi dua program, yaitu desa Mandiri OKMS dan BUMDes. Tahapan Proses dijelaskan: tahap persiapan kegiatan, tahap implementasi, manajemen organisasi, mekanisme pengiriman bantuan, untuk evaluasi dan pelaporan. Tujuan program Mandiri di Desa Nagrog menggambarkan bagaimana manajemen bisnis melalui BUMDes dan bagaimana implementasi proyek infrastruktur yang dikelola oleh OKMS.

Kata kunci: implementasi, kebijakan, program, desa, dan mandiri. 


\section{PENDAHULUAN}

$\mathrm{B}$

entuk perhatian dalam rangka mewujudkan peningkatan kesejahteraan masyarakat, Pemerintah Provinsi Jawa Barat meluncurkan Program/ Kegiatan Desa Mandiri di Provinsi Jawa Barat yang diformulasikan dalam bentuk bantuan keuangan khusus dari pemerintah Provinsi Jawa Barat langsung kepada Pemerintah Desa. pendanaan disalurkan melalui APBD Provinsi Jawa Barat.

Program Desa Mandiri ini ditujukan pada sasaran dan kegiatan yang sesuai dengan karakteristik dan masalah yang dihadapi oleh masing-masing desa. Sesuai dengan tugas pokok dan fungsi Organisasi Perangkat Daerah (OPD) Provinsi Jawa Barat, bahwa yang di dalamnya erat kaitannya dengan pembangunan pemberdayaan masyarakat dan pemerintahan desa, sehingga yang menjadi leading sector Program/Kegiatan Desa Membangun Menuju Desa Mandiri di Provinsi Jawa Barat adalah Badan Pemberdayaan Masyarakat dan Pemerintahan Desa (BPMPD) Provinsi Jawa Barat.

Prioritas dalam hal ini, yaitu: segala bentuk kegiatan yang terkait dalam bidang ekonomi, pendidikan, kesehatan, keamanan dan ketertiban, kedaulatan politik, peran serta masyarakat dan kinerja pemerintahan desa dalam rangka mewujudkan Desa Membangun Menuju Desa Mandiri.

Landasan pemikiran program /kegiatan Desa Membangun Menuju Desa Mandiri di Provinsi Jawa Barat, yaitu:

1. Masyarakat Provinsi Jawa Barat adalah masyarakat agamais dengan kekayaan warisan budaya dan nilai-nilai luhur tradisional yang sangat tinggi.

2. Berdasarkan data BPS jumlah penduduk Jawa Barat pada akhir tahun 2019, yaitu 49.565.2 juta jiwa, penduduk miskin di desa $36.88 \%$.
3. Banyaknya bantuan dari pusat, provinsi, kabupaten/kota ke desa yang kurang sinergis dan bersifat top down.

4. Meningkatnya angka pengangguran dan urbanisasi di desa.

5. Menurunnya tingkat kepercayaan masyarakat terhadap pemerintahan dan lembaga kemasyarakatan desa.

6. Infrastruktur perdesaan saat ini kurang memadai dan kondisinya secara umum rusak.

7. Kualitas Sumber Daya Manusia Aparatur dan Kelembagaan Masyarakat Desa rendah.

8. Peran stratejik terhadap kontribusi pembangunan dari aspek fisik, ekonomi, sosial, dan budaya belum mendukung secara signifikan terhadap pembangunan, padahal desa sebagai salah satu pusat pertumbuhan pembangunan.

9. Banyaknya potensi desa Sumber Daya Alam dan Sumber Daya Manusia yang layak untuk dikembangkan ${ }^{1}$.

Pada hakekatnya desa Mandiri adalah desa yang maju kehidupan lahir bathin meliputi bidang ekonomi, pendidikan, kesehatan, keamanan dan ketertiban, kedaulatan politik, peran serta masyarakat dan kinerja pemerintahan desa. Kemudian yang disebut Desa Mandiri adalah desa yang dilengkapi dengan berbagai fasilitas sosial yang memadai seperti sarana dan prasarana, kesehatan pendidikan, ekonomi, ibadah, olahraga, hiburan dan perbelanjaan dan lainlain.

Tujuan dari program/kegiatan ini, diharapkan dapat membantu Pemerintah dan Masyarakat Desa mengatasi permasalahan yang ada di Desa, antara lain meliputi:

\footnotetext{
1 Petunjuk Teknis Desa Peradaban Pemerintah Provinsi Jawa Barat 2010
} 
1. Penambahan modal dalam rangka penguatan ekonomi (Permodalan, Teknologi, dan Pemasaran).

2. Pembangunan infrastruktur perdesaan, yaitu antara lain: infrastruktur sarana dan prasarana perekonomian (jalan, jembatan, irigasi, pasar desa dan sarana ekonomi lainnya) infrastruktur sarana dan prasarana kesehatan (mandi cuci kakus, saluran pembuangan air limbah, pendukung sarana dan prasarana posyandu dan lain-lain), infrastruktur sarana dan prasarana sosial, kantor desa, gedung olah raga, lahan terbuka hijau, sarana peribadatan atau sarana perkantoran lainnya

3. Kegiatan padat karya produktif melalui kegiatan kelompok usaha perdagangan, usaha perbengkelan, percetakan, perikanan, pertanian, Peternakan, Usaha Produktif Pariwisata dan lain-lain².

Program/Kegiatan Desa Membangun Menuju Desa Mandiri di Jawa Barat diperuntukkan bagi desa yang berpotensi untuk maju dan mandiri dalam rangka mempercepat pencapaian peningkatan kesejahteraan masyarakat Desa dengan memberdayakan Pemerintah dan Masyarakat Desa melalui pendayagunaan sumber daya lokal secara mandiri dan sumber daya pembangunan secara optimal.

Berdasarkan hal tersebut, Desa Nagrog sebagai salah satu pemenang terbaik dalam lomba desa tingkat Kabupaten Bandung tahun 2019. Dengan mempunyai jumlah penduduk pada akhir tahun 2019, yaitu 16.108 juta jiwa, laki-laki 8.180 perempuan 7.928, jumlah kepala keluarga 5.046 penduduk.

Desa Nagrog mendapatkan desa terbaik dari 159 desa di Kecamatan Cicalengka dan mendapat juara I pada Temu Karya Nasional, Gelar Teknologi Tepat Guna (TTG) XX dan Pekan Inovasi Perkembangan Desa

2 Petunjuk Teknis Kegiatan Desa Peradaban, ibid. dan Kelurahan 2018 dibuka Presiden RI Joko Widodo, Jumat, 19 Oktober 2018. yang mendapat penghargaan dari pemerintah berupa empat unit maskara yang diserahkan langsung oleh Bupati Bandung, sedangkan dari Pemprov Jabar Mobil Aspirasi Kampung Juara.

Kabupaten Bandung mempunyai desa mandiri yang paling banyak dari kabupaten lainnya, jumlah 26 desa mandiri pada 2019 dan 56 pada 2020. Hal itu sudah nilai fantastis Kabupaten Bandung, karena di dalamnya terdapat potensi wilayah yang kaya oleh sumber daya alam yang didukung oleh sumber daya manusia, hal tersebut dikemukakan pada saatacara Penandatangan Kesepakatan Penetapan Status Desa Melalui Indeks Desa Mandiri (IDM) di Rumah Jabatan Bupati Bandung, (Pemkab Soreang, Selasa 7/7/2020).

Desa-desa yang terpilih dari 56 desa di antaranya: Desa Wates, Desa Kujangsari, Desa Lebakmuncang, Desa Nengkelan, Desa Panundaan, Desa Panyocokan, Desa Rawabogo, Desa Sukawening, Desa Lampegan, Desa Neglasari Desa Sindangmukti, Desa Panumbangan, Desa Panembong, Desa Katapang, dan Desa Jatisari. sebagai desa penerima manfaat program melalui Keputusan Gubernur Jawa Barat Nomor 147/Kep.290-BPMPD/2010 tentang Lokasi Program Desa Mandiri dalam Perwujudan Desa Mandiri di Jawa Barat 2010².

Program ini melalui tahapan yang sangat panjang selama kurun waktu 18 bulan dimulai sejak Mei 2010, yakni melalui program lomba desa, dilanjutkan dengan verifikasi oleh tim independen dari Provinsi Jawa Barat dan setelah menunggu selama kurun waktu 8 bulan berikutnya barulah diputuskan bahwa Desa Nagrog sebagai peserta program dalam perwujudan Desa Mandiri di Jawa Barat yang dikukuhkan melalui keputusan gubernur.

3 Keputusan Gubernur Jawa Barat, ibid. 
Pada 21 November 2018, Program Desa Mandiri di Desa Nagrog dimulai dengan menggarap secara serentak empat belas proyek infrastruktur yang dijalankan oleh OKMS (Organisasi Keswadayaan Masyarakat) dan melaksanakan simpan pinjam melalui program pengembangan ekonomi BUMDes (Badan Usaha Milik Desa).

Tujuan yang ingin dicapai dari program ini adalah peningkatan kesejahteraan bagi masyarakat Desa Nagrog dengan indikator Bertambahnyainfrastruktur Pendidikanyang menimbulkan peningkatan terhadap kualitas Pendidikan, bertambahnya infrastruktur Kesehatan yang menimbulkan peningkatan kualitas kesehatan, dan bertambahnya daya beli yang diakibatkan adanya peningkatan kuantitas dan kualitas usaha masyarakat, dan pada giliranya ketiga hal tersebut bisa meningkatkan Index Pembangunan Manusia (IPM)

Menurut pengamatan awal penulis di Desa Nagrog, ada beberapa masalah yang muncul sebelum dan setelah Program Desa Mandiri ini bergulir. Masalah pertama, yaitu kurangnya sosialisasi Pemerintah Kabupaten Bandung dan Pemerintah Provinsi Jawa Barat mengenai Program Desa Mandiri ini kepada masyarakat perdesaan terutama masyarakat Desa Nagrog yang mendapatkan program bantuan ini sehingga masyarakat Desa Nagrog sendiri pada awalnya kurang mengerti program apa yang akan dijalankan di desanya itu, seharusnya pemerintah Provinsi Jawa Barat menyosialisasikan jauh sebelum Program Desa Mandiri ini digulirkan, baik sosialisasi yang langsung terjun ke desa maupun sosialisasi yang memanfaatkan media seperti media cetak dan media elektronik.

Pemerintah Desa Nagrog sendiri melalui proses yang sangat berat dan sulit, yaitu harus menyisihkan banyak desa di Kabupaten Bandung untuk mendapat program bantuan Desa Mandiri ini, yaitu menyisihkan 159 desa menjadi 26 desa terpilih melalui persyaratan yang cukup rumit, dan ini menjadi beban tersendiri untuk pemerintah Desa Nagrog dikarenakan sumber daya manusia (SDM) di Desa Nagrog masih kurang pada saat itu.

Sumber daya manusia (SDM) dan Fasilitas desa yang masih kurang/terbatas menjadi hambatan berikutnya bagi Pemerintah Desa Nagrog yang pada saat itu harus menyelesaikan proposal pengajuan dengan tenggat waktu yang sangat singkat, sedangkan Desa Nagrog sendiri pada saat itu tidak memiliki komputer desa sendiri, serta sumber daya manusia yang dimiliki Pemerintah Desa Nagrog belum paham untuk menyelesaikan proposal yang harus dibuat tersebut.

Tidak adanya pelatihan pra program oleh Pemerintah Provinsi Jawa Baratmenjadi masalah/hambatan yang dikeluhkan oleh Pemerintah Desa Nagrog, pada saat sebelum menjalankan program Pemerintah Desa Nagrog hanya mendapatkan seminar/ pengarahan sehari saja dan tidak ada pelatihan khusus mengenai Program Desa Mandiri ini, dan ini membuat Desa Nagrog sedikit kesulitan dalam menjalankan Program Desa Mandiri ini di samping itu sumber daya manusia (SDM) dan fasilitas yang ada di Desa Nagrog sangat kurang atau bisa dibilang tidak ada seperti yang sudah dijelaskan di atas. Empat kali mengganti nama program yang berdampak pada beberapa kali pergantian proposal sangat menyulitkan bagi Pemerintah Desa Nagrog.

Sebelum Program Desa Mandiri ini dilaksanakan, Pemerintah Provinsi Jawa Barat beberapa kali mengganti nama program ini, dan setiap pergantian atau perubahan nama Pemerintah Desa Nagrog harus membuat ulang proposal yang diajukan kepada Pemerintah Provinsi Jawa Barat. Dan masalah ini kembali lagi berkaitan dengan sumber daya manusia dan fasilitas yang dimiliki oleh Desa Nagrog yang sangat terbatas. 
Penggunaan dana yang sangat singkat membuat Desa Nagrog kewalahan dalam mengatur dana dan waktu dalam program Desa Mandiri ini. Dana turun bulan Oktober sementara ke akhir anggaran tersisa dua bulan, yaitu bulan Desember, jadi pemerintah Desa Nagrog pada saat itu hanya menggunakan dana Desa Mandiri sebesar satu miliar dalam waktu dua bulan. Sedangkan banyak program yang membutuhkan waktu lebih dari dua bulan, seperti program infrastruktur. Efek lainnya, yaitu pemerintah Desa Nagrog harus mengatasi tenaga kerja, ketersediaan tenaga kerja yang dimiliki Desa Nagrog bisa dibilang sangat minim khususnya tenaga kerja ahli dalam bidang pembangunan khususnya dalam menjalankan program infrastruktur. Serta masalah lainnya yang muncul, yaitu masalah cuaca, saat program ini berlangsung, yaitu pada akhir tahun sedang musim hujan yang bisa menghambat pada program infrastruktur yang dijalankan sehingga dikawatirkan pada saat itu keterlambatan penyelesaian infrastruktur dalam kurun waktu dua bulan program ini dijalankan.

Dana sebesar satu miliar yang harus mencakup 14 (empat belas) proyekyangharus dijalankan terasa kurang oleh Pemerintah Desa Nagrog sendiri, sehingga proyek-proyek yang dijalankan baru setengah jadi belum seratus persen rampung/selesai, karena kebijakannya, yaitu harus mencakup semua sektor dari sektor pendidikan, kesehatan, ekonomi, sosial dan budaya. Dan pada saat program ini selesai masih ada beberapa proyek yang belum rampung namun dananya sudah habis atau tidak cukup, dan adanya pajak per item pada setiap program yang dijalankan, pajak yang dikenakan, yaitu mulai dari sebesar $10 \%$ sampai $11,5 \%$.

\section{Masalah Penelitian}

Berdasarkan dari penjelasan pada pendahuluan di atas, maka dapat dirumuskan masalah penelitian sebagai berikut.
1. Bagaimana Implementasi Kebijakan Program Desa Mandiri dalam Meningkatkan Kesejahteraan Masyarakat di Desa Nagrog Cicalengka Kabupaten Bandung Provinsi Jawa Barat?

2. Tujuan apa saja yang ingin dicapai dalam program Desa Mandiri yang dilaksanakan di Desa Nagrog Cicalengka Kabupaten Bandung Provinsi Jawa Barat?

\section{TINJAUAN PUSTAKA}

James E. Anderson mendefinisikan kebijakan publik yang dikutip oleh Subarsono $^{4}$ mengungkapkan bahwa: "Kebijakan publik sebagai kebijakan yang ditetapkan oleh badan-badan dan aparat pemerintah. Walaupun kebijakan publik dapat dipengaruhi oleh para aktor dan faktor dari luar pemerintah".

Kebijakan publik adalah kebijakan yang dibangun oleh badan dan pejabat pemerintah,yangimplikasikan darikebijakan tersebut adalah: 1) kebijakan publik selalu mempunyai tujuan tertentu atau tindakantindakan yang berorientasi pada tujuan; 2) kebijakan publik berisi tindakan-tindakan pemerintah; 3) kebijakan publik merupakan apa yang benar-benar dilakukan oleh pemerintah, jadi bukan merupakan apa yang masih dimaksudkan untuk dilakukan; 4) kebijakan publik yang diambil bisa bersifat positif yang artinya merupakan tindakan pemerintah yang mengenai suatu masalah tertentu, atau bersifat negatif dalam artian keputusan pemerintah yang tidak melakukan sesuatu; 5) kebijakan pemerintah yang positif setidaknya didasari oleh peraturan perundangan yang bersifat mengikat dan memaksa.

Van Meter dan Van Horn, mendefinisikan implementasi kebijakan sebagai: "Tindakantindakan yang dilakukan baik oleh individu-

4 Subarsono, Analisis Kebijakan Publik, Pustaka Pelajar, Yogyakarta, 2011, hlm. 2 
indvidu atau pejabat-pejabat atau kelompokkelompok pemerintah atau swasta yang diarahkan pada tercapainya tujuan-tujuan yang telah digariskan dalam keputusan kebijaksanaan Agustino ${ }^{5}$.

Riant Nugroho $^{6}$ mendefinisikan implementasi kebijakan dalam bukunya yang berjudul Public Policy, yaitu:

Implementasi kebijakan pada prinsipnya adalah cara agar sebuah kebijakan dapat mencapai tujuannya. Tidak lebih tidak kurang. Untuk mengimplementasikan kebijakan publik, ada dua pilihan langkah yang ada, yaitu langsung mengimplementasikan dalam bentuk program atau melalui formulasi kebijakan derivat atau turunan dari kebijakan publik tersebut.

Kebijakan publik dalam bentuk Undangundang atau Perda adalah jenis kebijakan publik yang memerlukan kebijakan publik penjelas atau yang sering diistilahkan sebagai peraturan pelaksana. Kebijakan publik yang bisa langsung operasional antara lain Keppres, Inpres, Kepmen, Keputusan Kepala Daerah, Keputusan Kepala Dinas, dan lainlain. Rangkaian implementasi kebijakan, dari gambar di atas, dapat dilihat dengan jelas, yaitu dimulai dengan program, ke proyek, dan ke kegiatan.

Berdasarkan dari hal tersebut, bahwa implementasi program/kebijakan merupakan pelaksanaan keputusan yang dilakukan oleh badan-badan terkait untuk mencapai suatu tujuan.Sehingga dapat disimpulkanbahwaimplementasimerupakan tahap kebijakan antara pembentukan program dan konsekuensi kebijakan terhadap masyarakat yang dipengaruhinya. Kemudian Apabila suatu program tidak tepat dan tidak bisa mengurangi masalah pada

5 Leo Agustino, Dasar-dasar Kebijakan Publik, Alfabeta, Bandung, 2008, hlm. 139

6 Riant Nugroho, Public Policy, PT Elex Media Computindo, Jakarta, 2011 hlm.. 618 sasaran kebijakan, maka program tersebut akan mengalami kegagalan sekalipun program tersebutdilaksanakan dengan baik, dan sebaliknya bila suatu program yang baik tidak menutup kemungkinan akan menghadapi kegagalan apabila program tersebut kurang dalam pelaksanaannya atau diimplementasikannya dengan baik. dari hal tersebut tersebut dapat diperoleh gambaran bahwa pelaksanaan program Desa Mandiri, mempunyai peran penting dan menentukan dalam menanggulangi masalah di perdesaan yang merupakan sasaran kebijakan dari Pemerintah Provinsi Jawa Barat.

\section{METODE PENELITIAN}

\section{Desain Penelitian}

Desain penelitian merupakan suatu rencana tentang cara mengumpulkan dan menganalisis data agar dapat dilaksanakan secara ekonomis serta serasi dengan tujuan penelitian ini. Maka yang dimaksud dengan penelitian adalah suatu proses untuk mencari dan mendapatkan secara sistematik dalam jangka waktu tertentu.

Metode penelitian yang digunakan, yaitu metode deskriptif Subana ${ }^{7}$, yaitu "Menuturkan dan menafsirkan data yang berkenaan dengan fakta, keadaan, variabel dan fenomena yang terjadi saat penelitian berlangsung dan menyajikan apa adanya. Definisi lain dijelaskan oleh Suchman dalam Nazir ${ }^{8}$, bahwa Penelitian Deskriptif adalah:

Suatu metode dalam meneliti status kelompok manusia, suatu sistem $\mathrm{p}$ e mikiran ataupun kondisi, suatu peristiwa pada masa sekarang. Tujuan dari penelitian deskriptif ini adalah memberikan gambaran atau lukisan secara sistematis, faktual dan akurat menge-

7 Subana, Dasar-Dasar Penelitian Ilmiah., Pustaka Setia, Bandung, 2005, hlm. 89

8 Nazir, Metode Penelitian, Ghalia Indonesia, Jakarta, 2005, hlm. 99 
nai fakta-fakta serta hubungan antara fenomena-fenomena yang diselidiki.

Penelitian deskriptif bertujuan untuk mendeskripsikan objek yang diteliti, dan di dalamnya terdapat upaya mengamati, mendeskripsi, mencatat, serta menganalisis. Adapun alasan peneliti menggunakan metode deskriptif, yaitu untuk menggambarkan dan menjelaskan bagaimana "Implementasi Kebijakan Program Desa Mandiri dalam Meningkatkan Kesejahteraan Masyarakat di Desa Nagrog Kecamatan Cicalengka Kabupaten Bandung Provinsi Jawa Barat".

Sedangkan pendekatan yang digunakan dalam penelitian, yaitu "Metode Kualitatif" yang dikemukakan oleh Sugiyono ${ }^{9}$, bahwa:"Metode kualitatif adalah suatu metode penelitian yang digunakan untuk meneliti pada kondisi objek yang dialami (sebagai lawannya adalah eksperimen), di mana peneliti adalah instrument kunci".

$\begin{array}{cc}\text { Kemudian menurut Sugiama" } & \text {, } \\ \text { mengemukakan } & \text { bahwa: }\end{array}$ penelitian kualitatif adalah prosedur suatu penelitian yang mengumpulkan data berupa kata-kata tertulis atau lisan dari orangorang dan perilaku yang dapat diamati secara deskriptif". Adapun alasan peneliti menggunakan metode kualitatif dalam penelitian ini, yaitu untuk lebih menjelaskan pemaparan berdasarkan fakta-fakta yang nyata dengan cara pengumpulan data-data yang akurat berdasarkan wawancara dengan pihak yang terkait.

Sumber Data yang diperlukan Menurut Sugiyono ${ }^{11}$, berdasarkan sumbernya, data dapat dibedakan menjadi dua, yaitu data primer dan data sekunder. Berikut penjelasannya:

9 Sugiyono, Memahami Penelitian Kualitatif, CV.Alfabeta, Bandung, 2005, hlm. 4

10 GimaSugiama, Metode Riset Bisnis dan Manajamen, Guardaya Intimarta, Bandung, 2008, hlm 31

11 Sugiyono, Metode Penelitian Kuantitatif Kualitatif dan R\&D,CV.Alfabeta, Bandung, 2010, hlm. 225
1. Sumber Data Primer;

Sumber data yang secara langsung memberikan data kepada pengumpul data (Sumber primer ini berupa catatan hasil wawancara yang diperoleh melalui wawancara yang penulis lakukan. Selain itu, penulis juga melakukan observasi lapangan dan mengumpulkan data dalam bentuk catatan tentang situasi dan kejadian di perpustakaan.

2. Sumber Data Sekunder;

Data yang tidak memberikan informasi secara langsung kepada pengumpul data. Sumber data sekunder ini dapat berupa hasil pengolahan lebih lanjut dari data primer yang disajikan dalam bentuk lain atau dari orang lain. Data ini digunakan untuk mendukung infomasi dari data primer yang diperoleh baik dari wawancara, maupun dari observasi langsung ke lapangan.Penulis juga menggunakan data sekunder hasil dari studi pustaka.Dalam studi pustaka, penulis membaca literatur-literatur yang dapat menunjang penelitian, yaitu literatur-literatur yang berhubungan dengan penelitian ini.

3. Penentuan Informan Menurut Spradley dalam Sugiyono ${ }^{12}$, menyatakan bahwa:

Dalam penelitian kualitatif, tidak menggunakan istilah populasi tetapi oleh Spradley dinamakan "sosial situation" atau situasi sosial yang terdiri dari tiga elemen, yaitu : tempat (place), pelaku (actors), dan aktivitas (activity) yang berinteraksi secara sinergi. Sampel dalam penelitian kualitatif bukan dinamakan responden, tetapi sebagai narasumber, atau partisipan, informan, teman, dan guru dalam penelitian.

Penentuan narasumber dilakukan secara purposive, yaitu dengan cara memilih orang-orang tertentu didasarkan pada

12 Sugiyono, ibid, hlm.49-50 
pertimbangan informasi yang diperlukan dan memiliki pengetahuan tentang masalah yang diteliti, sebanyak lima orang, yaitu: Kepala Desa Nagrog, Sekretaris Desa Nagrog, Organisasi Pengelola Kegiatan Pembangunan, Bendahara Kegiatan, Pengawas Kegiatan, Pelaksana Kegiatan (OKMS) yang terdiri dari: a. Ketua pelaksana kegiatan, b. Juru bayar, c. Pelaksana, dan Masyarakat Desa Nagrog di antaranya: 1) Petani, 2) Pedagang, 3) Anggota BPD, 4) Karangtaruna, 5) Pegawai Poskesdes.

Kemudian teknikpengumpulan datayang penulis gunakan, yaitu dengan Melakukan a. Observasi yang mengamati secara langsung pada objek penelitian, b. wawancara (Indepth interview) yang dikemukakan oleh Nazir $^{13}$, bahwa metode wawancara adalah "proses memperoleh keterangan dengan cara tatap muka dan tanya jawab pada narasumber yang menggunakan panduan wawancara(interview guide). Kemudian Esterberg dalam Sugiyono ${ }^{14}$ mengemukakan bahwa:

Wawancara/interview, yaitu a meeting of two persons to exchange information and idea through question and responses, resulting in communication and joint construction of meaning about a particular topic (Wawancara merupakan pertemuan dua orang untuk bertukar informasi dan ide melalui tanya jawab, sehingga dapat dikonstruksikan makna dalam suatu topik tertentu).

Dan c. Dokumentasi yang dilakukan penulis, yaitu dengan cara mengumpulkan dokumen dalam bentuk peraturan daerah atau keputusan ataupun petunjuk pelaksanaan (Juknis), dan dokumen lainnya yang dipandang penting yang menyangkut desa mandiri atau desa Mandiri. Seperti halnya Keputusan Gubernur Jawa Barat Nomor 978/ Kep.1131-BPMPD/2010 tentang Bantuan

13 Nazir, ibid, hlm. 193

14 Sugiyono, ibid, hlm. 231
Keuangan Dalam Rangka Desa Membangun Menuju Desa Mandiri di Jawa Barat, Peraturan Desa Nagrog Nomor: 05 Tahun 2010 tentang Pedoman Penggunaan Dana Bantuan Kegiatan Desa Mandiri Dalam Perwujudan Desa Mandiri dan petunjuk teknis dasa Mandiri.

Selanjutnya operasional konsep berdasarkan penjelasan teori dan konsep dari Van Meter dan Van Horn (1975: 463) yang diolah penulis 2020 tentang implementasi kebijakan yang penulis kemukakan untuk mengukur variabel, yaitu sebagai berikut.

1. Aktivitas implementasi dan komunikasi antarorganisasi dalam Implementasi Kebijakan Program Desa Mandiri harus berjalan dengan baik dengan memperhatikan koordinasi komunikasi di antara organisasi yang terlibat pelaksana kebijakan dalam menangani Implementasi Kebijakan Program Desa Mandiri itu sendiri dalam bentuk aktivitas implementasi yang baik dan bersinergi satu dengan lainnya.

2. Karakteristik agen pelaksana/ implementator dalam pelaksanaan kebijakan menangani Implementasi Kebijakan Program Desa Mandiri adalah bagian yang sangat dasar dari pengimplementasian kebijakan. Karena kinerja implementasi akan sangat dipengaruhi oleh implementatornya itu sendiri, serta dalam pelaksanaan kebijakan menangani Implementasi Program Desa Mandiri dibutuhkan agen kualitas dan kuantitas dalam melaksanakan kebijakan tersebut, agen pelaksana ini harus diisi oleh orangorang yang terampil dalam bidangnya masing-masing supaya kebijakan dalam menangani Implementasi Program Desa Mandiri berjalan sesuai dengan rencana yang telah ditetapkan.

3. Kondisi ekonomi,sosial, dan politikdalam kebijakan menangani Implementasi Kebijakan Program Desa Mandiri. Ketiga 
kondisi tersebut dapat memengaruhi kebijakan ini dapat berjalan dengan baik atau tidak. Dengan melihat kondisi dari faktor eksternal, yaitu ekonomi, sosial dan politik yang kondusif kebijakan menangani Implementasi Kebijakan Program Desa Mandiri akan berjalan dengan baik namun sebaliknya jika faktor eksternal tersebut tidak kondusif maka Implementasi Program Desa Mandiri tidak akan berjalan dengan baik pula, jadi ketiga kondisi tersebut memengaruhi terhadap jalannya implementasi kebijakan menangani Implementasi Program Desa Mandiri itu sendiri.

4. Kecenderungan (disposition) pelaksana/ implementator dalam Implementasi Kebijakan Program Desa Mandiri sikap para pelaksana kegiatan sangat memengaruhi dari kebijakan menangani Implementasi Kebijakan Program Desa Mandiri itu sendiri melalui pengambilan keputusan yang mereka buat atau sepakati sebelumnya, sehingga adanya kesediaan dan komitmen dalam melaksanakan kebijakan yang dibutuhkan. Selain itu juga diperlukannya koordinasi yang baik antarorganisasi internal maupun organisasi eksternal agar permasalahan segera terselesaikan.

Teknik Analisis Data adalah Proses analisisdatadimulaidenganmenelaahseluruh data yang tersedia dari berbagai sumber, yaitu wawancara, pengamatan, yang sudah ditulis dalam catatan lapangan, dokumen pribadi, dokumen resmi, gambar foto, dan sebagainya. Menurut Silalahi ${ }^{15}$ "Analisis data adalah proses penyederhanaan data dan penyajian data dengan pengelompokannya dalam satu bentuk yang mudah dibaca dan diinterprestasikan". Sedangkan menurut

15 Ulber Silalahi, Metode Penelitian Sosial, Refika Aditama, Bandung, 2010, hlm. 332
Sedarmayanti ${ }^{16}$ menjelaskan bahwa "Analisis data diperuntukkan agar peneliti dapat mengembangkan kategori dan sebagai perbandingan yang kontras untuk menemukan sesuatu yang mendasar dan memberi gambaran apa adanya". Kemudian teknik pengujian keabsahan data terdiri dari (tiga) alur kegiatan antara lain: a. Reduksi data, merupakan sebagai proses pemilihan, pemusatan perhatian pada penyederhanaan, mengabstraksikan, dan transformasi data kasar yang muncul dari catatan-catatan tertulis di lapangan, dan mengorganisasi data sedemikian rupa hingga simpulan, b. Penyajian data, merupakan alur kedua, di mana kumpulan informasi tersusun dan pengambilan tindakan sampai mendapat simpulan, c. Menarik simpulan, merupakan alur ketiga, yaitu menarik simpulan dan verifikasi terjadi ketika penganalisis mulai mencari kecocokan-kecocokan, polapola, konfigurasi-konfigurasi yang saling keterkaitan dan menunjukkan sebab akibat serta validasi data.

Ketiga alur proses tersebut di atas menggambarkan suatu tindakan cross check atau konfirmasi terhadap kebenaran, yang digabungkan dengan hasil wawancara,observasi dan melalui dokumentasi, kemudian ditarik suatu simpulan yang sebenarnya dari hasil temuan penelitian.

\section{HASIL PENELITIAN}

Variabel yang Menentukan Keberhasilan Implementasi Program Desa Mandiri

Dalam Proses Implementasi Kebijakan Program Desa Mandiri dalam Meningkatkan Kesejahteraan Masyarakat di Desa Nagrog Kecamatan Cicalengka Kabupaten Bandung Provinsi Jawa Barat ada empat variabel yang

16 Sedarmayanti.,Manajemen Sumber Daya Manusia, Refika Aditama, Bandung, 2014, hlm. 166 
menentukan keberhasilan dari implementasi Program Desa Mandiri berikut ini.

- Aktivitas Implementasi dan Komunikasi Antarorganisasi

Aktivitas implementasi dan komunikasi antarorganisasi dalam Implementasi Kebijakan Program Desa Mandiri dalam Meningkatkan Kesejahteraan Masyarakat di Desa Nagrog Kecamatan Cicalengka Kabupaten Bandung Provinsi Jawa Barat, dimulai dengan dibentuknya dua organisasi kemasyarakatan, yaitu BUMDes (Badan Usaha Milik Desa) dan OKMS (Organisasi Keswadayaan Masyarakat), dua organisasi ini dibentuk untuk menjalankan aktivitas programyangakan dijalankan di Desa Nagrog, yaitu program badan usaha simpan pinjam melalui BUMDes dan program kegiatan infrastruktur melalui OKMS (Organisasi Pengelola Kegiatan Pembangunan dibentuk berdasarkan musyawarah antara RT, RW, LPM, Karang Taruna dan Organisasi Masyarakat yang difasilitasi oleh Kepala Desa Nagrog dan Camat Cicalengka).

Dua organisasi tersebut berjalan bersamaan dalam menjalankan program Desa Mandiri di Desa Nagrog dengan berkomunikasi dengan perangkat Desa Nagrog dan tim pengawas program dalam setiap program yang dijalankan oleh dua organisasi tersebut, secara terbuka dan diketahui oleh semua unsur masyarakat (transparan) melalui penyediaan media komunikasi dan informasi yang akurat dan mudah diakses oleh masyarakat Desa Nagrog.

\section{- Karakteristik Agen Pelaksana/ Implementator}

Karakteristik agen pelaksana/ implementator dalam pelaksanaan Implementasi Kebijakan Program Desa Mandiri dalam Meningkatkan Kesejahteraan Masyarakat di Desa Nagrog Kecamatan Cicalengka Kabupaten Bandung Provinsi Jawa Barat, karakteristik agen pelaksana yang pertama, yaitu karakteristik Badan Usaha Milik Desa (BUMDes) adalah badan usaha yang dikelola oleh masyarakat, dalam menjalankan usahanya dipimpin oleh seorang manager yang diangkat dan diberhentikan oleh Kepala Desa atas pertimbangan Pengurus BPD, karakteristik pelaksana yang kedua, yaitu Organisasi Keswadayaan Masyarakat (OKMS) adalah program penggerak kegiatan infrastruktur yang dikelola oleh Ketua pelaksana kegiatan, Juru bayar, dan Pelaksana serta penyelenggaraan kegiatan dilakukan bersama masyarakat Desa Nagrog.

\section{- Kondisi Ekonomi, Sosial, dan Politik}

Kondisi ekonomi, sosial, dan politik dalam Implementasi Kebijakan Program Desa Mandiri dalam Meningkatkan Kesejahteraan Masyarakat di Desa Nagrog Kecamatan Cicalengka Kabupaten Bandung Provinsi Jawa Barat,Desa Nagrog sendiri adalah desa yang mayoritas masyarakatnya bergerak di sektor pertanian dan perkebunan sehingga sumber ekonomi masyarakat Desa Nagrog datang dari hasil bumi pertanian yang ada di Desa Nagrog Sendiri.

Kondisi sosial masyarakat Desa Nagrog sendiri sama seperti masyarakat perdesaan di Jawa Barat pada umumnya, masih sangat erat ikatan kekeluargaan antarmasyarakat satu dengan yang lainnya, dan masih sangat menjunjung tinggi kultur budaya adat istiadat serta norma-norma yang sudah ada sejak dulu di Desa Nagrog. Dan yang terakhir adalah kondisi politik masyarakat Desa Nagrog yang tidak terlalu terpengaruh pada politik yang ada di luar Desa Nagrog sendiri, partisipasi politik yang dilakukan masyarakat Desa Nagrog hanya ada pada masa pemilihan umum saja seperti pemilu presiden, kepala daerah dan yang terkhir pemilu kepala desa yang diselenggarakan setiap lima tahun sekali. 


\section{- Kecenderungan (disposition) Pelaksana/Implementator}

Kecenderungan (disposition) pelaksana/ implementatordalam Implementasi Kebijakan Program Desa Mandiri dalam Meningkatkan Kesejahteraan Masyarakat di Desa Nagrog Kecamatan Cicalengka Kabupaten Bandung Provinsi Jawa Barat, kecenderungan pelaksana/implementator yang ada di dua organisasi pelaksana Desa Mandiri di Desa Nagrog, di antaranya:

1. Kepala Desa Nagrog sebagai Penanggung Jawab program adalah bertanggung jawab terhadap seluruh pelaksanaan kegiatan pembangunan baik fisik maupun non fisik di Desa Nagrog.

2. Penanggung Jawab Kegiatan adalah Sekretaris Desa Nagrog yang diangkat sebagai penanggung jawab dalam pelaksanaan kegiatan baik fisik maupun non fisik.

3. Organisasi Pengelola Kegiatan Pembangunan dibentuk berdasarkan musyawarah antara RT, RW, LPM, Karang Taruna, Tokoh Masyarakat dan Organisasi Masyarakat yang difasilitasi oleh Kepala Desa Nagrog dan Camat Cicalengka.

4. Bendahara Kegiatan, yaitu: petugas (Staf Desa/Bendahara Desa) yang ditunjuk oleh penanggung jawab program sebagai pembantu Kepala Desa Nagrog dalam melaksanakan administrasi keuangan.

5. Pengawas program, yaitu: Staf Desa Nagrog sendiri yang diangkat oleh penanggung jawab kegiatan untuk mengawasi pelaksanaan pekerjaan.

6. Pelaksana Kegiatan, yaitu: Organisasi masyarakat Setempat (BPD, LPM, Karang Taruna, Tokoh masyarakat yang sudah dipilih berdasarkan hasil musyawarah desa).

Dan berikut adalah Proses dari Implementasi Kebijakan Program Desa Mandiri dalam Meningkatkan Kesejahteraan
Masyarakat di Desa Nagrog Kecamatan Cicalengka Kabupaten Bandung Provinsi Jawa Barat yang dibagi menjadi dua bagian organisasi pengelola Program Desa Mandiri di Desa Nagrog Kecamatan Cicalengka Kabupaten Bandung, di antaranya:

- Kegiatan Peningkatan Perekonomian Desa melalui BUMDes (Badan Usaha Milik Desa)

Tujuan Badan Usaha Milik Desa, yaitu di antaranya untuk meningkatkan perekonomian desa, meningkatkan pendapatan asli desa (PADes), meningkatkan pengelolaan potensi desa sesuai dengan kebutuhan masyarakat dan menjadi tulang punggung pertumbuhan dan pemerataan ekonomi desa.

- Kegiatan Infrastruktur melalui OKMS (Organisasi Keswadayaan Masyarakat)

Dipilihnya Organisasi Keswadayaan Masyarakat (OKMS) dalam penggunaan alokasi dana Desa Mandiri di sektor kegiatan peningkatan infrastruktur di Desa Nagrog, yaitu berdasarkan Keputusan Gubernur Jawa Barat Nomor 147/Kep.290-BPMPD/2010 tentang lokasi Program Desa membangun menuju Desa Mandiri di Jawa Barat dan Petunjuk Teknis Pelaksanaan Program/ Kegiatan Desa Membangun Menuju Desa Mandiri di Jawa Barat Tahun Anggaran 2010, agar Termanfaatkannya dana bantuan oleh Desa melalui kegiatan Organisasi Masyarakat (OKMS) sesuai dengan rencana kegiatan yang telah ditetapkan dan proporsi alokasi yang telah ditentukan serta diproyeksikan dalam RKP Desa dan RPJMDes, bertambahnya jumlah sarana/prasarana/ infrastruktur Desa Nagrog, meningkatnya kualitas sarana/prasarana/infrastruktur Desa Nagrog, meningkatnya Aksesibilitas masyarakat terhadap pembangunan, bertambahnya jumlah sarana/prasarana usaha, meningkatnya kesempatan berusaha bagi masyarakat Desa Nagrog, terserapnya 
tenaga kerja masyarakat Desa Nagrog, meningkatnya partisipasi (swadaya) masyarakat dalam kegiatan pembangunan serta termanfaatkannya sarana dan prasarana perekonomian Desa Nagrog yang telah dibangun Organisasi Masyarakat (OKMS) oleh BUMDes. Selanjutnya Program Desa membangun menuju Desa Mandiri di Jawa Barat Tahun 2010 merupakan bagian dari kebijakan publik yang dikeluarkan oleh pemerintah Provinsi Jawa Barat ini dapat dilihat oleh keputusan yang dikeluarkan oleh Pemerintah Provinsi, seperti yang telah dijelaskan pada Bab 2 yang dikutip oleh Dr. Riant Nugroho dalam bukunya yang berjudul "Public Policy" dari Peraturan Menteri Negara Pemberdayaan Aparatur Negara Nomor: PER/04/M.PAN/4/2007 Tanggal 7 April 2007 dalam lampiran 1 tentang "Pedoman Umum Formulasi, Implementasi, Evaluasi Kinerja, dan Revisi Kebijakan Publik di Lingkungan Lembaga Pemerintah Pusat Dan Daerah", yaitu "Kebijakan Publik adalah keputusan yang dibuat oleh pemerintahan atau lembaga pemerintahan untuk mengatasi permasalahan tertentu, untuk melakukan kegiatan tertentu atau untuk mencapai tujuan tertentu yang berkenaan dengan kepentingan dan manfaat orang banyak"17.

\section{SIMPULAN}

Berdasarkan uraian sebelumnya mengenai Implementasi Kebijakan Program Desa Mandiri dalam Meningkatkan Kesejahteraan Masyarakat di Desa Nagrog Kecamatan Cicalengka Kabupaten Bandung Provinsi Jawa Barat maka dapat ditarik simpulan sebagai berikut.

1) Proses Implementasi Kebijakan Program Desa Mandiri dalam Meningkatkan Kesejahteraan Masyarakat di Desa Nagrog Kecamatan Cicalengka Kabupaten Bandung Provinsi Jawa Barat Prosesnya dibagi menjadi dua kegiatan

17 Riant Nugroho, ibid. hlm.740 di antaranya yaitu, kegiatan perencanaan peningkatan perekonomian Desa melalui BUMDes (Badan Usaha Milik Desa) dan kegiatan perencanaan infrastruktur melalui OKMS (Organisasi Keswadayaan Masyarakat).

2. Tujuan Implementasi Kebijakan Program Desa Mandiri dalam Meningkatkan Kesejahteraan Masyarakat di Desa Nagrog Kecamatan Cicalengka Kabupaten Bandung Provinsi Jawa Barat melalui dua kegiatan di antaranya, yaitu Program pengembangan ekonomi melalui BUMDes Arya Kamuning Desa dan pembangunan infrastruktur oleh OKMS Desa Nagrog.

\section{SARAN}

Dari hasil pembahasan dan simpulan yang telah disajikan di atas, pada bagian ini penulis memberikan saran-saran sebagai masukan atau pertimbangan bagi Pemerintah yang mungkin bermanfaat untuk perbaikan dan penyempurnaan mengenai Implementasi Program Desa Mandiri. Adapun saran-saran yang ingin penulis sampaikan adalah sebagai berikut.

1. Pemerintah Kabupaten Bandung dan Pemerintah Provinsi Jawa Barat harus terlebih dahulu menyosialisasikan mengenai Program Desa Mandiri pada masyarakat perdesaan terutama masyarakat Desa Nagrog.

2. Harus adanya pengawasan dan bimbingan dari Pemerintah Provinsi maupun Pemerintah Kabupaten yang lebih intensif dalam pelaksanaan program Desa Mandiri.

3. Harus adanya pelatihan sebelum program dilaksanakan oleh Pemerintah Provinsi Jawa Barat kepada masyarakat Desa Nagrog itu sendiri.

4. Karena banyaknya program yang dijalankan maka Pemerintah Provinsi harus menambah jumlah anggaran 
untuk program desa Mandiri, karena masih banyak program yang belum terselesaikan.

Pelaksanaan Program Desa Mandiri seharusnya dilaksanakan pada awal tahun bukan akhir tahun karena mempertimbangkan banyak faktor di antaranya faktor waktu yang mendesak karena tutup tahun dan faktor lain seperti musim atau cuaca yang bisa menghambat dalam kelancaran pelaksanaan program.

\section{DAFTAR PUSTAKA}

Leo Agustino, Dasar-dasar Kebijakan Publik, Alfabeta, Bandung, 2008

Meter, Donald Van, dan Carl Van Horn, 1975. The Policy Implementation Process: A Conceptual Framework.http://aas. sagepub.com/content/6/4/445

Nazir. 1988. Metode Penelitian. Jakarta: Ghalia Indonesia.

Riant Nugroho, Public Policy, PT Elex Media Computindo, Jakarta, 2011

Silalahi, Ulber. 2010. Metode Penelitian Sosial. Bandung :Refika Aditama.

Sedarmayanti. 2014. Manajemen Sumber Daya Manusia. Bandung: Refika Aditama.

Subarsono, Analisis Kebijakan Publik, Pustaka Pelajar, Yogyakarta, 2011
Subana. 2005. Dasar-Dasar Penelitian Ilmiah. Bandung: Pustaka Setia.

Sugiama.Gima.2008. Metode Riset Bisnis dan Manajamen.Bandung :Guardaya Intimarta.

Sugiyono. 2010.Metode Penelitian Kuantitatif Kualitatif dan R\&D. Bandung: CV.Alfabeta.

Spradley, Sugiyono. 2010.Metode Penelitian Kuantitatif Kualitatif dan R\&D. Bandung: CV.Alfabeta.

\section{Peraturan Perundang-Undangan}

Peraturan Menteri Negara Pemberdayaan Aparatur Negara Nomor: PER/04/M. PAN/4/2007 Tanggal 7 April 2007 dalam lampiran 1 tentang Pedoman Umum Formulasi, Implementasi, Evaluasi Kinerja, dan Revisi Kebijakan Publik di Lingkungan Lembaga Pemerintah Pusat Dan Daerah

Keputusan Gubernur Jawa Barat Nomor: 978/ Kep.1131-BPMPD/2010 tentang Bantuan Keuangan dalam Rangka Desa Membangun menuju Desa Mandiri di Jawa Barat

Juknis Desa Mandiri Pemerintah Provinsi Jawa Barat Tahun Anggaran 2010. 